\title{
Study Viability and Survival Microflora of Cheeses Under the Influence of Freezing and Low-Temperature Storage
}

\author{
I V Buyanova* and Kuular Ch.G \\ Kemerovo State University, Krasnaya, Str. 6, Kemerovo, 650043, Russian Federation
}

*Corresponding author: IV Buyanova, Kemerovo State University, Krasnaya, Str. 6, Kemerovo, 650043, Russian Federation

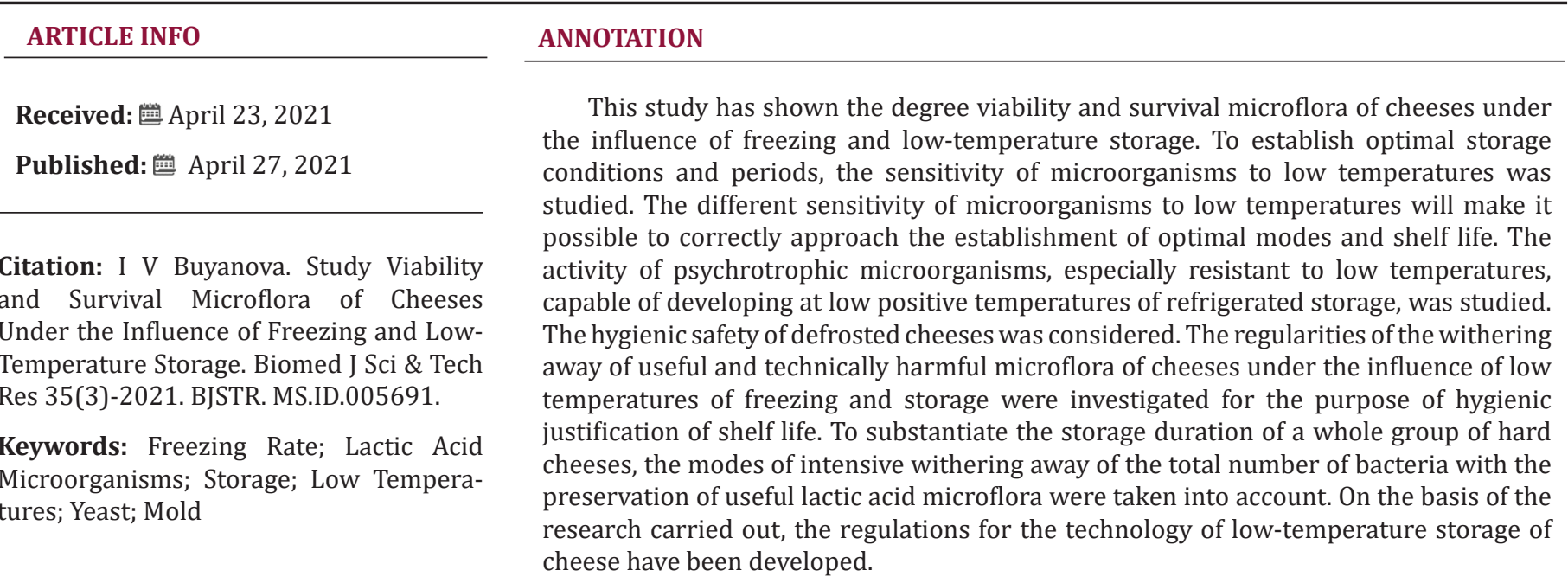

\section{Introduction}

Currently, Russia is actively developing and producing fermented milkproducts enriched with useful microflora, the range is expanding due to the creation of new types of fermented milk products. It is a generally accepted fact that fermented milk products improve the health of the human body. The production of fermented milk products is based on the use of starter cultures of microorganisms in the form bacterial concentrates, which are specially selected and prepared combinations of lactic acid bacteria [1-3]. The most important characteristics that determine the quality of food products are their safety and microbiological resistance. Safety is understood as the absence of harmful impurities of a chemical and biological nature, including pathogenic microorganisms and toxic products of their vital activity. Microbiological resistance implies the potential for preserving food without spoilage $[2,4,5]$. Low temperatures have peculiarities in their effect on various types of microorganisms. Some of them, being transferred to favorable conditions after prolonged exposure to low temperatures, lose their ability to develop or develop extremely weakly; others, on the contrary, are developing well. In this regard, it is advisable to study the survival of microflora, including sanitary indicative, pathogenic and opportunistic groups of microorganisms after low-temperature long-term storage. The vital activity of microorganisms is one of the main causes of changes in food products during storage. By changing environmental conditions and exerting one or another effect on the product, it is possible to regulate the composition and activity of microflora, limiting or preventing the reproduction of pathogenic and technically harmful microflora [3,6-9].

\section{All this Indicates the Urgency of the Problem Under Discussion}

Previous studies have shown that, nevertheless, in conditions of deep freezing, leading to a state of suspended animation, microorganisms only partially die. However, after thawing the 
product, microorganisms remaining during freezing can reactivate and multiply, negatively affecting the quality. During refrigerated storage, psychrophilic microorganisms most actively manifest their vital activity, causing biochemical processes leading to a deterioration in the quality of products. In this regard, we should especially talk about the physiological and biological properties of microscopic molds and yeasts, which have high lipolytic and proteolytic activity. The consequence of their multiplication in cheeses during refrigerated storage is the appearance of defects of the following nature: rancidity, salting, unpleasant odor, deterioration of the presentation of the product. In addition, mesophilic microorganisms, including conditionally pathogenic and sanitary-indicative microorganisms, the excess of which can lead to human intoxication, can persist in frozen products. Ensuring hygienic conditions for production and storage is important because the synthesized enzymes and toxins can act even after the death of the microorganisms themselves. Therefore, in order to preserve the quality of the product during freezing and lowtemperature storage, it is necessary to create such temperature regimes of refrigeration processing that would be below the temperature limits for the growth of the most stable psychrophilic microorganisms. To establish the expected shelf life, one or another temperature regime was selected taking into account the dynamics of changes in the state of microflora.

Yeast and mold fungi have the lowest minimum development temperatures (minus $2 \ldots$ minus $10 \stackrel{\circ}{\circ}$ ), and at a rather low water activity. If at low temperatures yeast and mold are resistant and able to grow, then at the same temperatures mesophilic bacteria already die off or their vital activity slows down significantly $[2,10$, 11]. In our opinion, it is advisable to consider the microbiological aspects of low-temperature cheese storage technology, starting from the freezing stage. Consideration of the impact of freezing on microorganisms were considered from the point of view of a possible change in the quality of perishable products. In frozen form, cheeses can be stored for a long time without changing the quality, while maintaining organoleptic properties and satisfactory appearance... It is cost effective to use low temperature refrigeration. Storage at production bases and refrigerators with their subsequent transportation to distribution refrigerators and into the distribution network requires the creation of low temperatures and strict adherence to them [12-15]. The list of microbiological indicators under study has been expanded in comparison with the standardized indicators to obtain a detailed description of the sanitary and hygienic state of frozen cheeses. This series of studies examined the effect of freezing on the condition of opportunistic microflora that determines food safety.

\section{Objects and Methods}

The objects of low-temperature storage were selected hard rennet cheeses of various species groups. Among them were distinguished cheeses of the Soviet type (with a high temperature of the second heating), such as Holland (with a low temperature of the second heating) and Russian (with a high level of lactic acid fermentation). These cheeses are in the greatest demand and popularity in the domestic cheese market; therefore the task is to preserve the quality of these types of cheeses for a long period of time. An experimental stand has been developed and created to conduct research on freezing finely packaged cheeses by air. The prototypes were subjected to freezing in an air flow at a cooling medium temperature of minus $50{ }^{\circ} \mathrm{C}$ and minus $30{ }^{\circ} \mathrm{C}$. The design of the installation made it possible to change and maintain the temperature in the freezer to minus $100{ }^{\circ} \mathrm{C}$ and create an air speed of up to $10 \mathrm{~m} / \mathrm{s}$. The stand is equipped with two heat flow sensors, which are connected to the KSP-4 potentiometer and the thermocouple unit, the signal is transmitted to another KSP4 potentiometer. from - 40 to $-100 \stackrel{\circ}{\circ}$ accuracy class 0.5 . The air velocity in the freezer tunnel was measured with a T-3 hot-wire anemometer with a measurement error of $0.05 \mathrm{~m} / \mathrm{s}$. The total error in measuring temperatures $\varepsilon \mathrm{t}=6 \%$.

Thermograms of the process served as the main experimental material in the development of technological regulations for preliminary freezing of cheeses. With their help, the main indicators of the process were determined - the duration and average rate of freezing [15-18]. The shelf life of frozen cheeses was up to 18 months with two storage temperatures - minus $20{ }^{\circ} \mathrm{C}$ and minus $12{ }^{\circ} \mathrm{C}$. Investigated in dynamics indicators of microbial spoilage: yeast and mold in all tested samples. Microbiological control of experimental cheeses was carried out according to the following scheme: before freezing, after freezing and during low-temperature storage. The work used the generally accepted methods of quantitative accounting of microorganisms in food. The number of molds and yeasts was determined on Sabouraud's medium, the determination of bacteria of the E. coli group was carried out on Kessler's medium, coagulase-positive staphylococci on salt agar, bacteria of the genus Salmonella by inoculation on Kaufman's medium. The total number of bacteria, bacteria of the Escherichia coli group (BGKP), the amount of psychrotrophic microflora and the number of mesophilic aerobic and facultative anaerobic microorganisms (KMAFAM) were determined according to GOST 9225-84.

The determination of yeast and molds was carried out according to the method of GOST 10444.12-88, by the dish method on solid nutrient media. Determination of pathogenic microflora, including bacteria of the genus Salmonella, was carried out according to GOST R 50480 - 93. Inoculations on Kaufman's medium with transfer to Endo's medium. Determination of Staphylococcus aureus was carried out in accordance with GOST 30347-88. Cryoscopic temperature and some other thermophysical characteristics of cheeses were determined by differential scanning calorimetry. 


\section{Results and Discussion}

Microbiological control of experimental cheeses was carried out before freezing, the results of which are shown in Table 1. The results showed that the total number of bacteria at the time of freezing did not exceed 91 million bacteria in $1 \mathrm{~g}$ of Soviet cheese, 120 million bacteria in $1 \mathrm{~g}$ of Russian cheese and 210 million bacteria in $1 \mathrm{~g}$ of Dutch cheese. The initial quantitative composition of microflora differed by species groups and corresponded to the volume of microflora of mature cheese at the storage stage. The greatest number of bacteria was observed in cheeses with a low second heating temperature. The microflora of mature cheeses was represented mainly by lactic acid bacteria of starter cultures and foreign cultures with psychrotrophic properties. Since lactic acid bacteria determine the dietary properties of cheeses and have the ability to develop in packaged products without access to air, and psychrophilic species of this group, as well as yeast and mold, deteriorate the quality of cheese after defrosting and further storage, in this series of experiment studies were carried out on the ability of these microorganisms to transfer low temperatures and affect the quality of the cheeses. It is known that the death of microorganisms during freezing is mainly due to the temperature and the rate of freezing.

Table 1: Microbiological indicators of experimental cheeses.

\begin{tabular}{|c|c|c|c|}
\hline \multirow{2}{*}{$\begin{array}{c}\text { Microbiological } \\
\text { Indicators }\end{array}$} & \multicolumn{3}{|c|}{ Number Of Microorganisms, CFU / G } \\
\cline { 2 - 4 } & Soviet & Dutch Squared & Russian \\
\hline $\begin{array}{c}\text { Total bacteria count, } \\
\text { QMAFAnM }\end{array}$ & 9.1107 & 2.1108 & 12.0107 \\
\hline Lactic acid bacteria & 1.4106 & 2.1107 & 5.6106 \\
\hline $\begin{array}{c}\text { BGKP (coli-form), absent in g } \\
\text { of cheese }\end{array}$ & 0.01 & 0.01 & 0.01 \\
\hline Yeast, CFU / g, no more & \multicolumn{3}{|c|}{ absent } \\
\hline Molds CFU / g, no more & \multicolumn{3}{|c}{ absent } \\
\hline
\end{tabular}

Below are the results of studies on the effect of freezing on the survival of the main microflora of cheese. The patterns of bacterial death at different rates of cheese freezing are shown in Figure 1. The regularity of the process of dying off of microorganisms under the influence of low temperatures has been established. The results showed a rapid decrease in the number of bacterial cells, and the number of remaining cells depended on the speed of freezing. An increase in the freezing rate reduced the rate of bacteria death. So, at the lowest process speeds from (5.1 to 5.8).10-6 m / s, on average, $75-78 \%$ of KMAFAiM of the initial amount remained. In Soviet cheese, before freezing, the total number of bacteria was 9.1 . $107 \mathrm{CFU} / \mathrm{g}$, and after freezing, it decreased to 2.0 • $106 \mathrm{CFU} / \mathrm{g}$. In Dutch cheese, before freezing, the total number of bacteria was $2.1 \cdot 108 \mathrm{CFU} / \mathrm{g}$, and after freezing, it decreased to $4.2 \cdot 106 \mathrm{CFU}$ / g. Lactic acid bacteria tolerate freezing well enough. Apparently, the resistance to physical and chemical changes in the state of the environment was determined by the age of the bacterial cell (in the stationary phase) and the protective properties of the cheese buffer systems Figure 2.

With an increase in the freezing rate, the number of viable mesophilic aerobic and facultative anaerobic bacteria decreased less. Under these conditions, the dying off of microorganisms was less intense. So, in the speed range from (7.2 to 8.15).10 $10^{-6} \mathrm{~m} / \mathrm{s}$ (air temperature $-30{ }^{\circ} \mathrm{C}$ ) $78-79 \%$ of the total number of bacteria in all experimental cheeses survived. If before freezing the bacterial contamination of Russian cheese was equal to $1.2 \times 108 \mathrm{CFU} / \mathrm{g}$, then after the completion of this stage it decreased to $3.2 \times 106 \mathrm{CFU}$ / g. When using the rates (9.4 - 10.0).10-6 m / s (air temperature $-50{ }^{\circ} \mathrm{C}$ ) survived $82-83 \%$ of the total. These remaining bacteria tolerate low temperatures fairly well. Thus, negative temperatures have a detrimental effect on bacterial cells. Figure 3 Low freezing rates at an air temperature of - $20 \stackrel{\circ}{ } \mathrm{C}$ cause the greatest death of microorganisms. In this variant, the slow temperature drop, diffuse cell dehydration and extracellular ice formation cause a greater percentage of microbial damage. An increase in freezing rates leads to an increase in the resistance of bacteria to low temperatures. The results of microbiological studies have shown a relatively stable attitude towards freezing of lactic acid bacteria. The number of surviving microorganisms ranged from 78 to $85 \%$.

So, if the initial amount of lactic acid bacteria in Soviet cheese did not exceed $1.4 \times 106 \mathrm{CFU} / \mathrm{g}$, then after freezing at a rate of 5.1.10$6 \mathrm{~m} / \mathrm{s}$ their number remained $8.0 \cdot 104 \mathrm{CFU} / \mathrm{g}$, and at a higher speed 9.4 .10-6 m / s already 7.5 $105 \mathrm{CFU} / \mathrm{g}$ bacteria survived. At the next stage of research, the effect of freezing on opportunistic microflora was studied. The list of studied microbiological indicators has been expanded in comparison with the standardized indicators to obtain a detailed sanitary and microbiological characteristic of frozen products. The product safety criterion for the consumer is the content of microorganisms capable of forming toxins or the amount of a product containing a toxin (staphylococci, toxicogenic molds, salmonella, enteropathogenic E. coli). Investigated in dynamics indicators of microbial spoilage: yeast and mold in all tested samples. The data obtained show the death of molds and yeasts under the influence of low temperatures. Table 1 shows information characterizing the effect of freezing and refrigerated aging of hard cheeses on the amount of yeast and mold. The research results showed that the refrigeration treatment itself did not lead to a significant decrease in the number of cells and spores of yeasts and molds. Apparently, this is due to the specific structure of bacterial cells. Their death occurs most actively during storage.

The table shows that the most active death of yeast cells occurred in the first 2 months of storage at a temperature of - 12 ㅇ․ Then the process of death stabilized and, in the subsequent months of storage at - 12 으, a slight increase in yeast cells was observed in all cheese samples. After 12 months of storage, their content was: 
in the Soviet cheese - 1.1 $102 \mathrm{CFU} / \mathrm{g}$, in the Dutch cheese - 8.5 . $101 \mathrm{CFU} / \mathrm{g}$, in the Russian cheese - $1.1 \cdot 102 \mathrm{CFU} / \mathrm{g}$. For 18 months of storage at $-12{ }^{\circ} \mathrm{C}$, the amount of yeast continued to grow and equaled $1.3102 \mathrm{CFU} / \mathrm{g}$ in Soviet cheese, $1.5102 \mathrm{CFU} / \mathrm{g}$ in Russian cheese. These values amounted to an increase in Soviet cheese by $54 \%$, Russian cheese by $17 \%$, in Dutch cheese - by $250 \%$ compared to the values after freezing. At the same time, the number of yeast colonies during the entire storage period decreased regularly at a temperature of $-20 \stackrel{\circ}{\circ}$. By the end of storage, the yeast content changed by 1 order of magnitude in the Soviet and Holland cheeses and by 2 orders of magnitude in the Russian. The high viability of yeast cells even at low values of water activity $(\mathrm{Aw}=0.67-0.70)$ preserved the stability of these microorganisms after one and a half years of storage of frozen cheeses at negative temperatures. If the initial value of yeast in Dutch cheese was $4.4 \times 102 \mathrm{CFU} / \mathrm{g}$, in Soviet cheese $-2.4 \times 102 \mathrm{CFU} / \mathrm{g}$, then during storage it changed and amounted to $2.5 \times 102 \mathrm{CFU} / \mathrm{g}$ and 1, $3 \cdot 102 \mathrm{CFU} / \mathrm{g}$. Consequently, as a result of low-temperature storage at $-20 \stackrel{\circ}{ } \mathrm{C}, 60.0 \%$ of the original amount of yeast perished in frozen Holland cheese, and $54 \%$ in Soviet cheese. Due to the stability of yeast cells, to maintain viability in frozen cheeses at $-12 \stackrel{\circ}{\circ}$, the storage temperature should be controlled at a level not higher than minus $20 \stackrel{\circ}{ }$.

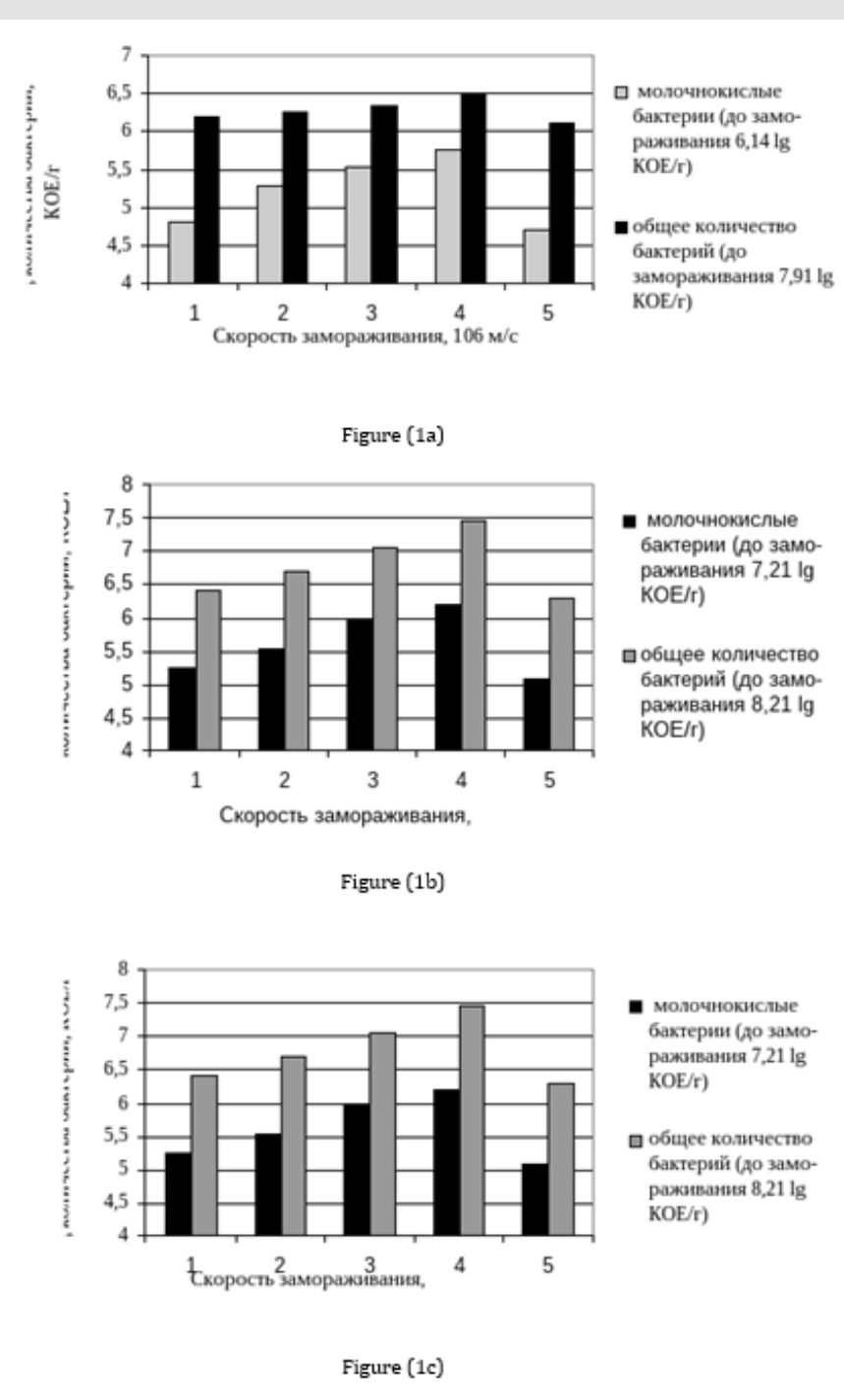

Figure 1: Bacterial survival in semi-hard cheeses at different freezing rates: a - Soviet, b - Russian, c - Gollandskiy. 


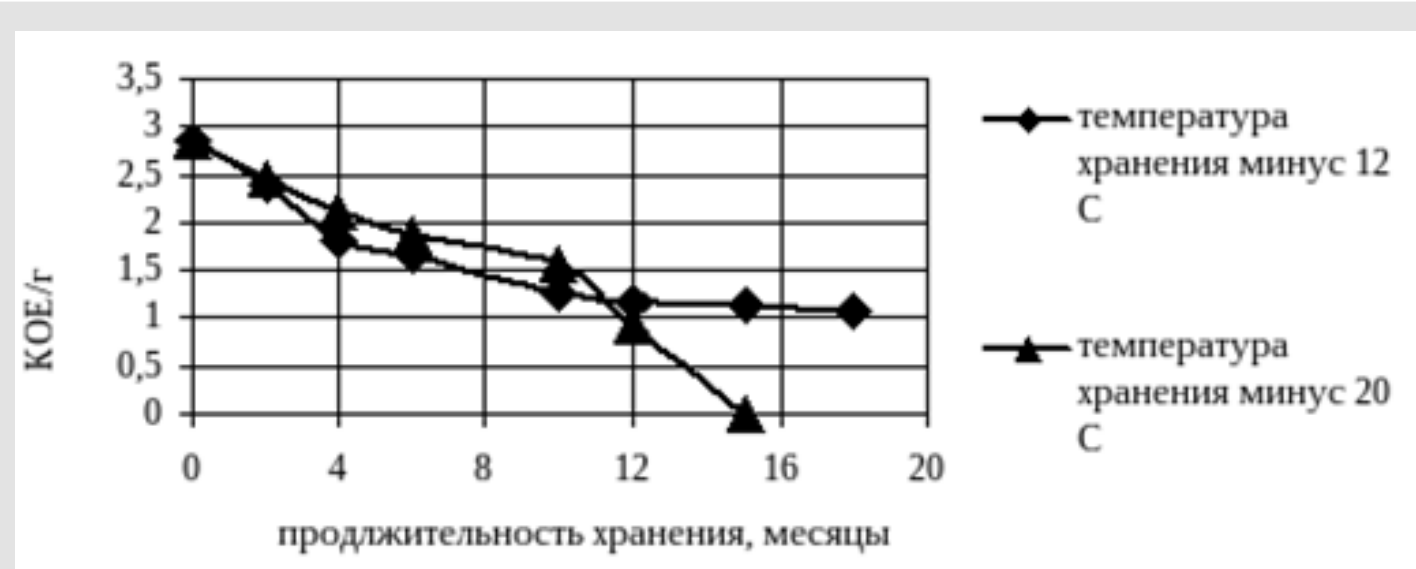

Figure 2: Dynamics of yeast cell death during low-temperature storage of Russian cheese.

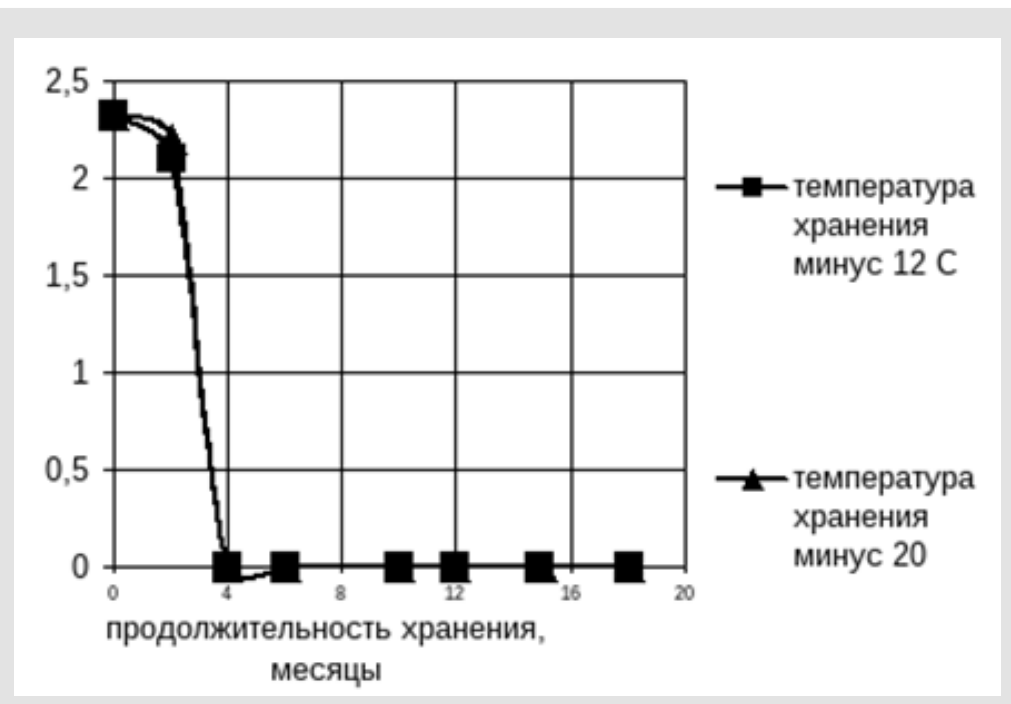

Figure 3: The dynamics of the death of mold fungi in the process of low-temperature storage of Russian cheese.

The vegetative forms of molds are more sensitive to temperature and died especially actively during storage. The vital activity of these microorganisms was limited by low values of water activity in the range of $0.75-0.70$. Their withering away took place in stages. At first, the number of microorganisms decreased during freezing from $4.3 \cdot 102$ to $1.0 \cdot 102 \mathrm{CFU} / \mathrm{g}$ in Soviet cheese, from $7.0 \cdot 102$ to $3.2 \cdot 102 \mathrm{CFU} / \mathrm{g}$ in Russian cheese, from 5, $6 \cdot 101$ to $2.2 \cdot 101 \mathrm{CFU} / \mathrm{g}$ in Dutch cheese. Despite the rather high resistance of bacteria (staphylococcus, salmonella, E. coli bacteria) to low temperatures known in scientific circles, their number gradually decreases at an unequal rate at the stage of freezing, long-term storage and short-term storage after thawing up to 1 month. The ultimate goal of low temperature food storage is to limit changes, especially those that degrade product quality. The organoleptic properties of frozen cheeses in terms of the main indicators are generally reduced by 10-12 points at the end of storage (18 months). In the control cheeses, after 6 months of storage in a refrigerated state, the decrease in the overall score was 5-7 points, due to their overripening. Sanitary indicative, conditionally pathogenic and pathogenic microorganisms died off at a storage temperature of minus $20 \circ \mathrm{C}$ and were not detected during further storage of defrosted cheeses. Recommended modes of low-temperature storage of cheese at minus $(20+-2) \stackrel{\circ}{\circ}$ prolong the shelf life by 2-3 times compared to traditional modes.

\section{Conclusion}

The research results showed that frozen cheeses after storage had satisfactory safety indicators for the consumer and were positively evaluated in terms of refrigeration and storage conditions, as well as shelf life. The remaining non-critical mass of microorganisms did not exceed the established standards of SanPiN 2.3.2.1078-01. Sanitary indicative, conditionally pathogenic and pathogenic microorganisms died off at a storage temperature of minus $20{ }^{\circ} \mathrm{C}$ and were not detected during further storage of defrosted cheeses. Recommended modes of low-temperature storage of cheese at minus $(20+-2){ }^{0} \mathrm{C}$ prolong the shelf life by $2-3$ 
times compared with traditional modes. Due to the high freezing speed, the period of bacterial activity is also reduced. Bacteria of different types have different temperature limits of vital activity. With slow freezing, traces of the vital activity of each type of bacteria appear, and with "shock" freezing, many of them do not have time to develop. Thus, the shelf life of quick-frozen food is longer than that of food frozen in conventional chambers.

To manage quality at the stage of low-temperature storage, it is necessary to know the optimal temperature conditions for the growth, reproduction or death of various groups of microorganisms, as well as the effect of low temperatures on the degree of their survival and the possibility of their reproduction in cheeses that can withstand freezing. Cheese stored in compliance with the technological regimes of freezing, storage, defrosting is favorable in sanitary and hygienic terms. At the end of storage, the results obtained indicate hygiene and good quality. In this case, the initial microbiological state of the cheeses before freezing and storage has a decisive influence. In the course of research, it was found that most of the microorganisms die off precisely at the freezing stage. The other part - slowly during frozen storage, as a result of which the proportions between the various groups of bacteria changes. Studies have made it possible to establish the resistance of lactic acid bacteria to low temperatures. The number of lactic acid microflora is reduced, on average, 100 times, remaining in a greater amount in the composition of cheese starter cultures, characterizing its dietary properties. Paradoxically, after freezing, beneficial types of bacterial cultures of lactic acid bacteria survive to a greater extent than at low positive temperatures of refrigerated storage. Microbiological analysis of frozen cheeses shows that it is acceptable for use after storage and that there is no danger of microbial spoilage.

\section{References}

1. Azarina S, Lee BH, Yaylayan V, Kilcawley KN (2010) Proteolysis development in enzyme-modified Cheddar cheese using natural and recombinant enzymes of Lactobacillus rhamnosus S93. Food Chemistry 120(1): 174-178.

2. Noronha N, Cronin D, O’Riordan D, O’Sullivan M (2008) Flavoring reduced fat high fiber cheese products with enzyme modified cheeses (EMCs). Food Chemistry110(4): 973-978.

3. Noronha N, Cronin D, O’Riordan D, O'Sullivan M (2008) Flavoring of imitation cheese with enzyme-modified cheeses (EMCs): Sensory impact and measurement of aroma active short chain fatty acids (SCFAs). Food Chemistry 106(3): 905-913.
4. Januszkiewicz J, Sabik H, Azarina S, Lee B (2008) Optimization of headspace solid-phase microextraction for the analysis of specific flavors in enzyme modified and natural Cheddar cheese using factorial design and response surface methodology. Journal of Chromatography A 1195(1-2): 16-24

5. Moskowitz GJ, Noelck SS (1987) Enzyme-Modified Cheese Technology. Journal of Dairy Science. 70 (8): 1761-1769.

6. Hannon JA, Kilcawley KN, Wilkinson MG, Delahunty CM, Beresford TP, et al. (2006) Production of ingredient-type Cheddar cheese with accelerated flavor development by addition of enzyme-modified cheese powder. Journal of Dairy Science 89 (10): 3749-3762.

7. McSweeney PLH (2004) Biochemistry of cheese ripening. International Journal of Dairy Technology. 2004; 57: 127-144.

8. Haileselassie SS, Lee BH, Gibbs BF (1999) Purification and identification of potentially bioactive peptides from enzyme-modified cheese. Journal of Dairy Science 82 (8): 1612-1617.

9. Mohebbi M, Barouei J, Akbarzadeh-T MR, Rowhanimanesh AR, HabibiNajafi MB, et al. (2008) Modeling and optimization of viscosity in enzyme-modified cheese by fuzzy logic and genetic algorithm. Computers and electronics in Agriculture 62(2): 260-265.

10. Kilcawley KN, Wilkinson MG, Fox PF (2006) A novel two-stage process for the production of enzyme-modified cheese. Food Research International 39(5): 619-627.

11. Ali B, Khan KY, Majeed H, Abid M, Xu L, Wu F, et al. (2017) Soymilk-Cow's milk ACE-inhibiting enzyme modified cheese. Food Chemistry 237: 1083-1091.

12. Bas D, Kendirci P, Salum P, Govce G, Erbay Z, et al. (2019) Production of enzyme-modified cheese (EMC) with ripened white cheese flavor: I-effects of proteolytic enzymes and determination of their appropriate combination. Food and Bioproducts Processing 117: 287-301.

13. Kilcawley KN, Wilkinson MG, Fox PF (2001) A survey of lipolytic and glycolytic end-products in commercial Cheddar enzyme-modified cheese. Journal of Dairy Science 84 (1): 66-73.

14. Ganina VI, MM Sonieva (2005) The influence of various cryoprotectants on the survival of probiotic cultures: scientific publication. MGUPB, pp. 187.

15. Buyanova IV, OV Krieger, IO Larina, VO Buyanov (2008) The role of low temperatures in assessing the microbiological state of frozen cheeses. Cheese making and butter making. No. 3: S25-S26.

16. Buyanova IV (2008) Technological principles of quality management for defrosting cheeses // Specialized magazine "Milk rivers", 4: 32-33.

17. Tsutsaeva AA (1983) Cryopreservation of cell suspensions / AA Tsutsaeva, V.A. Agranenko. - Kiev: Nauk. dumka. pp. 240.

18. Buyanova I (2014) Simulating the refrigeration of batch dairy products in a multizone cold supply system /I. Buyanova // Международныйнаучныйжурнал«Foods and Raw materials»: КемТИПП. - Кемерово 2014 (2) C: 121-129. 


\section{ISSN: 2574-1241}

DOI: 10.26717/BJSTR.2021.35.005691

I V Buyanova. Biomed J Sci \& Tech Res

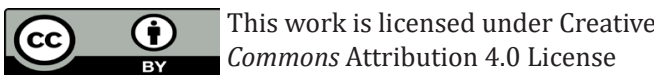

Submission Link: https://biomedres.us/submit-manuscript.php

$\begin{array}{ll}\text { BIOMEDICAL } & \text { Assets of Publishing with us } \\ \text { RESEARCHES } & \text { Global archiving of articles } \\ \text { - Immediate, unrestricted online access } & \text { - Rigorous Peer Review Process } \\ & \text { - Authors Retain Copyrights }\end{array}$

